\title{
Hairless Chinese Crested
}

National Cancer Institute

\section{Source}

National Cancer Institute. Hairless Chinese Crested. NCI Thesaurus. Code C53948.

The Hairless Chinese Crested is a variety of the Chinese Crested breed that is hairless except for its feet, head and tail. Height: 12 inches $(30 \mathrm{~cm}$.) Weight: not over 10 pounds $(4.5 \mathrm{~kg})$ 